\title{
EFFECT OF HALOTHANE ON MYOCARDIAL INFARCT SIZE IN RATS
}

\author{
Igor Kissin, Rex Stanbridge, Sanford P. Bishop and J.G. Reves
}

\begin{abstract}
The effect of halothane on myocardial infarction caused by ligation of the left descending coronary artery was studied in rats. The extent of infarction was quantified $\mathbf{4 8}$ hours after ligation of the artery by planimetric measurement of left ventricular slices stained with nitrobluetetrazolium. Animals exposed to halothane one per cent for three hours after the coronary ligation were compared with a control group which received halothane for only 5-7 minutes during surgery. It was found that halothane caused a small increase in infarction size ( $31.3 \pm 1.5$ per cent of the left ventricle compared to $25.7 \pm 2.3$ per cent, $p<0.05$ ). This effect was accompanied by a decrease in systolic blood pressure $(91 \pm 2 \mathrm{mmHg}$ compared to $113 \pm$ $3 \mathrm{mmHg}, \mathrm{p}<0.001$ ). Heart rate did not change significantly.

Analysis of our results in comparison to previously reported data on the effect of halothane on myocardial ischaemia in different experimental conditions shows that halothane may produce beneficial as well as detrimental effects on ischaemic injury to the myocardium. The latter can result when the drug causes marked hypotension in the absence of a significant decrease in heart rate.
\end{abstract}

KEY WORDS: ANAESTHESIA, halothane; HEART, myocardial infarct, halothane.

BLAND AND LowENSTEIN' demonstrated in dogs that halothane decreases the severity of myocardial ischaemia produced by repeated coronary occlusions and estimated by epicardial STsegment mapping. The importance of the problem of choice of anaesthetic for patients with ischaemic heart disease makes it interesting to assess the effect of halothane on ischaemic injury to the myocardium using a direct morphological method. In this study, the histochemical method by Nachlas and Schnitka ${ }^{2}$ was used.

\section{METHODS}

Experiments were conducted on SpragueDawley male rats, weighing $300-350 \mathrm{~g}$. Myocardial infarction was produced by a method similar to that described by Johns and Olson ${ }^{3}$ and Selye with co-workers. ${ }^{4}$ Each animal was initally anaesthetized with four per cent halothane which was delivered into a plastic bag enclosing the cage. After a two minute exposure, the animal was fastened to an operating board and anaesthesia was continued with two per cent halothane for approximately five minutes during coronary ar-

Igor Kissin, M.D., Ph.D., Associate Professor in Anesthesiology; Rex Stanbridge, F.R.C.S., M.R.C.P., Surgery Fellow; Sanford P. Bishop, D.V.M., Ph.D., Professor of Pathology; J. G. Reves, M.D., Professor in Anesthesiology, School of Medicine, University of Alabama, Birmingham, AL 35294, U.S.A.

Presented at the 7th World Congress of Anaesthesiologists, Hamburg, F.R.G. September 1980

Canad. Anaesth. Soc. J., vol. 28, no. 3, May 1981 tery ligation. Halothane was delivered through a tightly fitting face-mask while respiration was maintained with a respirator pump (Harvard Apparatus, Model 607). As a vaporizer, a recently calibrated Fluotec (Cyprane, Inc. FR type) was used. A reservoir bag was interposed between the pump and the vaporizer. A craniocaudal incision to the left and parallel to the sternum was made through the skin and pectoral muscles and a purse string suture was placed around the incision site (Figure 1). A left thora-

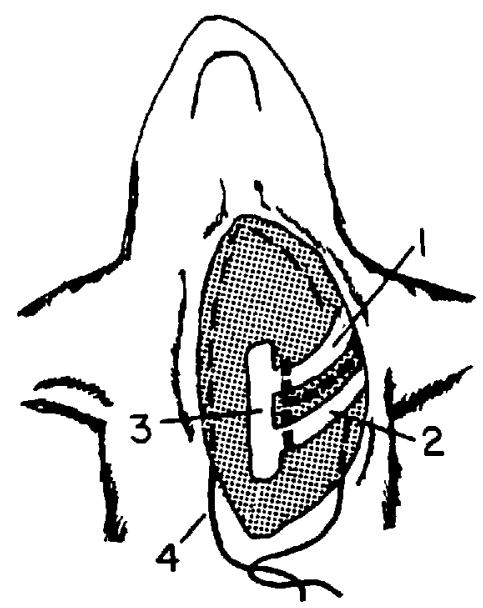

FIGURE 1 Incisions necessary for exteriorizing the heart. (1) Fourth rib; (2) Fifth rib; (3) Sternum; (4) Purse string suture. Thick interrupted lines - incisions for 239 
cotomy was done through the fourth intercostal space. The fourth and fifth ribs were separated and their cartilages were transected aproximately $0.5 \mathrm{~cm}$ to the left of the sternum. After exteriorization of the heart, the left descending coronary artery was ligated 5-6 $\mathrm{mm}$ from its origin with 6-0 Ethicon cardiovascular silk suture. The heart was replaced in the thorax, and the previously placed suture was closed. The period when the thorax remains open is short enough that the authors of this method ${ }^{3,4}$ did not use artificial ventilation. The rats were sacrificed $48 \mathrm{hrs}$ after ligation of the coronary artery, when the necrotic process was well established. ${ }^{5}$

Myocardial infarct size was estimated on tissues stained with nitrobluetetrazolium (NBT) reaction for the presence of intracellular dehydrogenase activity according to Nachlas and Schnitka. ${ }^{2}$ At the time of sacrifice, each rat was injected with heparin (100 units). Five minutes later the heart was excised, washed and placed in saline at $37^{\circ} \mathrm{C}$ for twenty minutes to promote development of rigor mortis to provide a uniform state of contraction among hearts. After rigor mortis developed, the heart was blotted dry and placed in the freezer for 20 minutes. When firm, the heart was cut from apex to the occluding ligature into three transverse slices. The slices were incubated for 15 minutes at $37^{\circ} \mathrm{C}$ in a potassium phosphate buffered solution of $0.05 \%$ NBT. Incubation with NBT resulted in an intense staining reaction in undamaged regions of the heart while areas of necrotic tissue appeared as clearly delineated pale zones. After fixation in 10 per cent buffered formalin, color photographs of the upper surface of each slice were taken with a polaroid camera (Polaroid Corp., MP-4) at a magnification of $10 \times$ (Figure 2). Total and infarcted area of the left ventricle were measured. The area of damaged myocardium on all three slices was expressed as a percentage of the total area of the left ventricular sections. The measurements were made by planimetry using a sonic digitizer (Graf-pen) interfaced to a Hewlett Packard $9825 \mathrm{~A}$ calculator system.

In a special series of experiments, when planimetric measurements of infarct size had been done, the unstained portions of the left ventricular myocardium were sharply dissected from the slices with the use of a micromanipulator and then weighed. The infarct volume and its percentage of the left ventricle were then calculated and compared with the results obtained from the planimetric method (Table I). Correlation be-

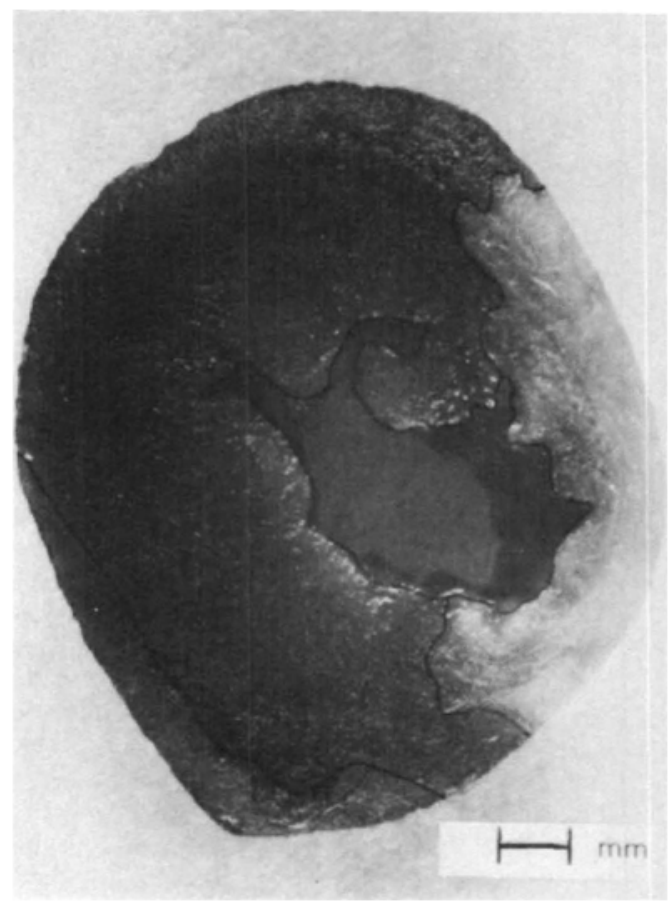

Figure 2 Entire heart slice $(10 x)$ with and infarction (48 hrs) demonstrated by nitrobluetetrazoljum staining.

TABLE I

COMParison of Two Methods of INFARCT Size MEASUREMENTS

\begin{tabular}{ccc}
\hline & \multicolumn{2}{c}{ Infarct size, \% of LV } \\
\cline { 2 - 3 } $\begin{array}{c}\text { No. of } \\
\text { exp. }\end{array}$ & $\begin{array}{c}\text { Sonic planimetry } \\
\text { (Graf-pen) }\end{array}$ & $\begin{array}{c}\text { Dissection with } \\
\text { micromanipulator } \\
\text { and weighing }\end{array}$ \\
\hline 1 & 21 & 22 \\
2 & 25 & 23 \\
3 & 26 & 24 \\
4 & 32 & 25 \\
5 & 27 & 72 \\
6 & 12 & 7 \\
7 & 10 & 29 \\
8 & 24 & $21.5 \pm 2.8$ \\
M & $20.9 \pm 5.1$ & \\
\hline
\end{tabular}

$r=0.91 ; p<0.01$.

tween the two sets of results was sufficiently high $(r=0.91, n=8, p<0.01)$.

The systolic blood pressure and heart rate were measured by an indirect tail-cuff method, using a programmed electro-sphygmomanometer (Narco Bio-Systems, Inc. PE-300). A tachograph (Grass, 7P4F) was used to follow changes in heart 
rate. Both parameters were recorded with a polygraph (Grass, model 7D). Before the measurement, the rat tail was heated for five minutes by a 75 -watt light bulb placed $10-12$ inches away from it.

The animals were randomly divided into two groups. The control group received halothane two per cent for about five minutes during the surgical procedure only; the halothane group received halothane one per cent for an additional three hours after ligation. The individual responsible for measuring the size of the infarction was "blinded" to the treatment. For the exposure to halothane, rats were placed in a transparent plastic cage connected to a calibrated Fluotec ${ }^{(8)}$ vaporizer with air passing through the vaporizer and the cage at a rate of two $1 / \mathrm{min}$. Rats of all groups were heated with an electric blanket placed under the cages. Rat temperature was monitored with rectal thermistor probes connected through a switch box to a telethermometer (Yellow Springs Inst. Co., Model 43). The temperature was maintained at $37^{\circ} \mathrm{C}$.

Halothane was furnished by Ayerst Laboratories, Inc. Nitrobluetetrazolium was purchased from Sigma Chemical Corp.

\section{RESULTS}

Thirty-nine rats were used, of which thirty survived coronary occlusion. Mortality rate in both groups of animals was almost equal. In the halothane group 15 rats survived and 5 died compared with 15 and 4 respectively in the control group.

In the control group infarct size was $25.7 \pm 2.3$ per cent of the left ventricle (Figure 3 ). Halothane caused a small increase in infarction size (31.3 \pm 1.5 per cent vs $25.7 \pm 2.3$ per cent, $\mathrm{p}<0.05$ ). Arterial blood pressure measured at the end of the three hour exposure to halothane was $91 \pm 2$ $\mathrm{mm} \mathrm{Hg}$ compared with $113 \pm 3 \mathrm{~mm} \mathrm{Hg}$ in the control ( $p<0.005)$. The difference between heart rate in the halothane ( $388 \pm 9$ beats $/ \mathrm{min})$ and control (402 \pm 5 beats $/ \mathrm{min}$ ) groups was not statistically significant.

\section{Discussion}

Our study has demonstrated that myocardial infarct size in rats anaesthetized with one per cent halothane for three hours was greater than in control animals.

Table II compares data from most of the studies examining halothane in the setting of

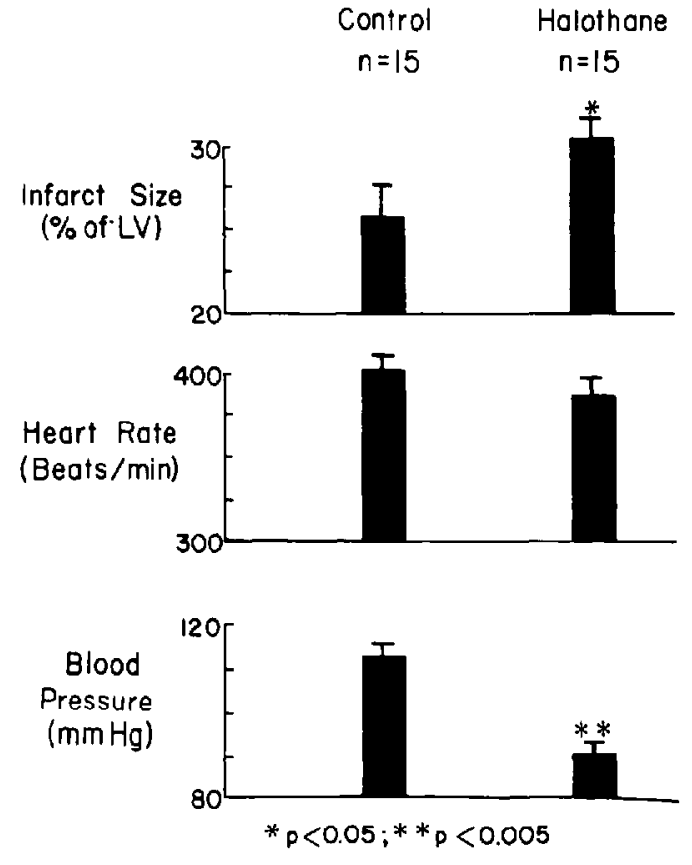

Figure 3 Effect of halothane one per cent for three hours on myocardial infarct size. Values are means \pm $\mathrm{SE}$.

experimental ischaemia. It is seen that the beneficial effect of halothane on myocardial ischaemia, first reported by Bland and Lowenstein, ${ }^{1}$ is a matter of controversy. Some of the authors ${ }^{7-9}$ could not confirm any improvement in the ischaemic region; in fact, they found changes that may be regarded as a tendency toward deterioration of energy demand/supply balance.

It is commonly held at present that factors increasing the oxygen demand increase the infarct size. Conversely, factors improving the oxygen supply reduce the infarct size. According to Opie," "confusion arises from the delicate balance between salutary and harmful effects of the specific interventions". Halothane appears to be an illustration of this. It may cause pronounced changes in heart rate and arterial pressure that have the opposite effects on ischaemia. It is well known that a decrease in heart rate has a beneficial effect on ischaemia and a decrease in arterial pressure a detrimental effect, due to reduction of the collateral blood supply. ${ }^{12-14}$ In our study, halothane did not change heart rate significantly and decreased arterial pressure. Therefore, it is conceivable to assume that the increase of myocardial infarct size was related to the reduced arterial pressure.

In a separate group of seven rats, we measured 
TABLE II

Halothane (0.75-1 percent) Treatment in Experimental Myocardial Hypoxia

\begin{tabular}{|c|c|c|c|c|c|c|c|}
\hline \multirow[b]{2}{*}{ Authors } & \multirow[b]{2}{*}{ Model } & \multirow{2}{*}{$\begin{array}{l}\text { Index of } \\
\text { Ischemia }\end{array}$} & \multirow{2}{*}{$\begin{array}{l}\text { Index } \\
\text { Change }\end{array}$} & \multicolumn{2}{|c|}{$\begin{array}{l}\text { Heart Rate } \\
\text { (Beats/min) }\end{array}$} & \multicolumn{2}{|c|}{$\begin{array}{l}\text { Arterial Pressure } \\
(\mathrm{mm} \mathrm{Hg})\end{array}$} \\
\hline & & & & Control & Halothane & Control & Halothane \\
\hline Bland, Lowenstein' & $\begin{array}{l}\text { Coronary } \\
\text { occlusion } \\
\text { in dogs }\end{array}$ & S T-segment & Improved & 160 & 139 & 119 & 108 \\
\hline Reves et $a l .^{7}$ & $\begin{array}{l}\text { Coronary } \\
\text { occlusion } \\
\text { in dogs }\end{array}$ & $\begin{array}{l}\text { S T-segment } \\
\mathrm{Pm}_{\mathrm{O}_{2}}\end{array}$ & $\begin{array}{l}\text { No change } \\
\text { Decreased } \\
\text { (trend) }\end{array}$ & 130 & 129 & 106 & 106 \\
\hline Moores, et al. ${ }^{8}$ & $\begin{array}{l}\text { Hypoxemia } \\
\text { in swine }\end{array}$ & $\mathrm{Pm}_{\mathrm{CO}_{2}}$ & Increased & \multicolumn{2}{|c|}{ Paced } & \multicolumn{2}{|c|}{ Controlled } \\
\hline Tinker, Harrison ${ }^{9}$ & $\begin{array}{l}\text { Coronary } \\
\text { occlusion } \\
\text { in dogs }\end{array}$ & ATP & $\begin{array}{l}\text { Decreased } \\
\text { (trend) }\end{array}$ & 157 & 153 & 116 & 69 \\
\hline Smith, et al. ${ }^{10}$ & $\begin{array}{l}\text { Coronary } \\
\text { occlusion } \\
\text { in dogs }\end{array}$ & $\begin{array}{l}\text { Coronary } \\
\text { venous } \\
\mathrm{Po}_{2}\end{array}$ & $\begin{array}{l}\text { Increased } \\
\text { (trend) }\end{array}$ & 158 & 135 & 124 & 79 \\
\hline
\end{tabular}

$\mathrm{Pa}_{\mathrm{O}_{2}}$ and $\mathrm{Pa}_{\mathrm{CO}_{2}}$ in the samples of blood taken from the carotid artery after three hours of exposure to one per cent halothane. $\mathrm{Pa}_{0_{2}}$ was $12.24 \pm 0.8 \mathrm{kPa}$ $(92 \pm 6 \mathrm{~mm} \mathrm{Hg})$ and $\mathrm{Pa}_{\mathrm{CO}_{2}} 6.25 \pm 0.4 \mathrm{kPa}(47 \pm$ $3 \mathrm{~mm} \mathrm{Hg}$ ). These data agree well with results reported by White and associates ${ }^{6}$ and show that there was no significant hypoxia. Therefore, the probability that the hypoxia might be the cause of increase in infarct size is extremely remote.

It is of interest that the authors ${ }^{7-9}$ (see Table II) who reported the tendency for increased severity of myocardial ischaemia after halothane did not observe significant changes in heart rate. At the same time, in experiments of Bland and Lowenstein ${ }^{1}$ and Smith and associates ${ }^{10}$ who reported a beneficial influence of halothane on regional myocardial ischaemia, there was a pronounced heart slowing effect. It is possible to suggest that the disparity between the results obtained in our experiments and those of Bland and Lowenstein is also due to the difference in heart rate changes under the influence of halothane.

Very pronounced heart slowing effect of halothane observed in some open-chest experiments on dogs ${ }^{1.10}$ is probably due to excessively high baseline heart rate - about 160 beats/min (normal canine heart rate is $70-100$ beats/min). In unanaesthetized dogs with normal baseline heart rate, halothane may even cause tachycardia. ${ }^{15,16}$

It would appear that when heart rate is decreased after halothane, the drug has a beneficial effect on ischaemic myocardium and when heart rate does not change, there is no benefit. That is in accordance with many experimental and clini- cal observations concerning the role of heart rate in myocardial ischaemia. ${ }^{17}$ Loeb and associates ${ }^{18}$ have recently shown that for similar increases in myocardial oxygen consumption, the stress from increased heart rate results in more myocardial ischaemia than the stress induced by increase in the afterload.

The possible detrimental effect of halothane on myocardial ischaemia is associated with its hypotensive effect, leading to decrease in coronary perfusion pressure. It has been shown recently that halothane depresses contractile function in the region of myocardial ischaemia caused by reduction in coronary inflow. This effect was prevented when the low level of perfusion to the ischaemic zone was controlled with a pump so that halothane could not cause any additional reduction in coronary inflow ${ }^{19}$. The authors write, "We believe that if halothane produces severe depression in situations wherein there is ischaemic myocardium, it is due to a combination of peripheral effects and generalized myocardial depression. We conclude that halothane does not produce greater functional depression in regions of myocardial ischaemia by a direct effect." These data are supported by clinical experience. Prys-Roberts and associates ${ }^{20}$ in a study with hypertensive patients, have shown that halothane induced hypotension may be a critical factor in reducing coronary blood flow to a degree where electrocardiographic evidence of ischaemia is present.

Analysis of our results in comparison with the data obtained by other authors regarding the 
effect of halothane on myocardial ischaemia in different experimental conditions shows that halothane may produce beneficial as well as detrimental effects on injury to the myocardium by ischaemia. The latter can result when the drug causes marked hypotension in the absence of significant decrease in heart rate.

\section{REFERENCES}

1. Bland, J.H.L. \& Lowenstein, E. Halothaneinduced decrease in exerimental myocardial ischemia in the non-failing canine heart. Anesthesiology 45: 287-293 (1976).

2. Nachlas, M.M. \& ShinitKa, T.K. Macroscopic identification of early myocardial infarcts by alterations in dehydrogenase activity. Am. J. Pathol. 42: 379-396 (1963).

3. JoHNS, T.N.P. \& Olson, B.J. Experimental myocardial infarction. I. A method of coronary occlusion in small animals. Ann. Surg. 140: 675-682 (1954).

4. Selye, H., Bajusz, E., Grasso. S. \& Mendell, $P$. Simple techniques for the surgical occlusion of coronary vessels in the rat. Angiology $11: 398-407$ (1960).

5. Fishbein, M.D., Maclean, D. \& Maroko, P.R Experimental myocardial infarction in the rat. Qualitative and quantitative changes during pathologic evolution. Am. J. Pathol. 90: 57-70 (1978).

6. White, P.F., Johnston, R.R. \& Eger, E.I. Determination of anesthetic requirement in rats. Anesthesiology 40: 52-57 (1974).

7. Reves, J.G., Mardis, M., ERdmanN, W. \& KarP, R.B. Effect of halothane on normal and ischemic canine myocardial $\mathrm{PO}_{2}$. (Abstr.) American Society of Anesthesiologists Annual Meeting 1977, pp. 253-254.

8. Moores, W.Y., Weiskopf, R.B., DembitsKY, W.P. \& UTLEY, J.R. Comparative effects of halothane and morphine anesthesia on myocardial function and metabolism during cyanosis in swine. Surgical Forum 30: 221-223 (1979).

9. Tinker, J.H. \& Harrison, C.E. Protection from myocardial ischemia: Role of anesthetics. Anesthesiology 5I: S58 (1979).
10. Smith, G., Rogers, K. \& Thorburn, J. Halothane improves the balance of oxygen supply to demand in acute experimental myocardial ischaemia. Br. J. Anaesth. 52: 577-583 (1980).

11. OPIE, L.H. Myocardial infarct size. Part I. Basic considerations. Am. Heart J. 100: 355-372 (1980).

12. Maroko, P.R., KJekshus, J.E., Sobel, B.E., Watanabe, T., Covell, J.W., Ross, J. \& BRAUNWALD, E. Factors influencing infarct size following experimental coronary artery occlusions. Circulation 43: 67-82 (1971).

13. Mauney, F.J., Jr., Ebert, P.A. \& Sabiston, D.C. Postoperative myocardial infarction: A study of predisposing factors, diagnosis and mortality in a high risk group of surgical patients. Ann. Surg. 172: 497-503 (1979).

14. Kissin, I. Reves, J.G. \& Mardis, M. Is the rate-pressure product a misleading guide? Anesthesiology 52: 373-374 (1980).

15. VATNER, S.F. \& SMITH, N.T. Effects of halothane on left ventricular function and distribution of regional blood flow in dogs and primates. Circ. Res. 34: 155-167 (1974).

16. Merin, R.G., Kumazawa, T. \& Luka, N.L. Enflurane depresses myocardial function, perfusion, and metabolism in the dog. Anesthesiology 45: S01-507 (1976).

17. OPIE, L.H. Myocardial infarct size Part 2. Comparison of anti-infarct effects of beta-blockade, glucose-insulin-potassium, nitrates and hyaluronidase. Am. Heart J. 100: 531-552 (1980).

18. Loeb, H.S., Saudye, M., Croak, R.P., Talano, J.B., KLODNICKY, M.L. \& GunNar, R.M. Effects of pharmacologically induced hypertension on myocardial ischemia in coronary hemodynamics in patients with fixed coronary obstruction. Circulation 57: 41-46 (1978).

19. Behrenbeck, T., Nugent, M., Quasha, A., Hoffman, E., Ritman, E. \& Tinker, J. Halothane and ischemic regional myocardial wall dynamics. Anesthesiology 53: S140 (1980).

20. Prys-Roberts, C.. Foex, P., Greene, T.L. \& WATERHouse, T.D. Studies of anesthesia in relation to hypertension; IV: The effects of artificial ventilation on the circulation and pulmonary gas exchanges. Br. J. Anaesth. 44: 335-349 (1972).

RÉSUMÉ

L'influence de l'administration d'halothane sur l'importance de l'infarctus produit par la ligature de la descendante antérieure chez le rat a été évaluée par des mesures planimétriques sur des tranches ventriculaires colorées au bleu de nitrozolium, 48 heures après la ligature de la coronaire. Aux fins de l'étude, on a comparé un groupe de rats auxquels l'on a administré de l'halothane à un pour cent durant 3 heures après la ligature de la descendante antérieure à un second groupe qui ont reçu l'halothane seulement durant la période de 5 à 7 minutes pendant laquelle on procédait à la chirurgie. Nous avons observé des infarctus plus importants chez les animaux ayant reçu l'administration prolongée d'halothane que chez ceux ne l'ayant reçu que pendant la chirurgie $(31.3 \pm 1.5 \%$ du ventricule gauche vs $25 \pm 2.3 \% ; \mathrm{p}<0.5)$. Nous avons également observé une diminution de la pression artérielle systolique chez ceux ayant reçu l'halothane durant 3 heures $(91 \pm 2 \mathrm{~mm} \mathrm{Hg}$ vs $113 \pm 3 \mathrm{~mm} \mathrm{Hg} ; \mathrm{p}<0.001)$. La fréquence cardiaque était comparable dans les deux groupes.

$L$ 'interprétation de ces résultats par rapport aux publications antérieures au sujet des effets de l'administration d'halothane sur l'ischémie myocardique, dans un contexte expérimental différent, indique que l'halothane peut avoir des effets bénéfiques ou nocifs sur l'étendue du dommage myocardique. Les effets nocifs surviennent lorsque cet agent produit une hypotension marquée non accompagnée d'un ralentissement parallèle de la fréquence cardiaque. 